\title{
Occupationless Health
}

\section{“Gissa job": the experience of unemployment}

\author{
RICHARD SMITH
}

Failing losing your job (not voluntarily quitting it) and taking a long time to get another one, the best way to begin to understand the "truth" about unemployment and to get within the skin of the experience is probably not to read reviews in the fournal of Applied Psychology or the BMF but to go and "hang around" on street corners in Sunderland, Wigan, or Brixton. There is, of course, a strong tradition of this sort of approach-Orwell did it in the $1930 \mathrm{~s}^{1}$ and Campbell ${ }^{2}$ and Seabrook ${ }^{3}$ have done it in the 1980s. Indeed, in the 1930s the gap between academic and literary/political/observational studies (call them what you will) was not as wide as it is now, and the classic study by Jahoda and others on Marienthal, an exsteel town in Austria where almost everybody was unemployed for nine years, grew from her and her politically committed friends leaving the lusher pastures of nearby Vienna and going to see what they could do to help the unemployed of Marienthal. ${ }^{4}$ They were "scientists" who did not believe in fading into the background.

In a similar vein, the outstanding review of all the work done in the 1930s on the psychological effects of unemployment places great importance on the writings of those with inside experience: it starts by imploring its scientific readers to try to grasp the "full, poignant, emotional feeling" of unemployment by reading a selected list of "novels, plays, and case material." Novels take longer to incubate than journalism so we must wait for best of the novels on unemployment in the $1980 \mathrm{~s}$, but in addition to the writings of Campbell and Seabrook and a host of rather dry studies of unemployment we have had Alan Bleasdale's popular television series, The Boys from the Blackstuff, Fagin and Little's descriptions of unemployment in families, ${ }^{6}$ Marsden's verbatim accounts from the unemployed (accompanied by Duff's photographs), ${ }^{7}$ and our own series from general practice. . $^{815}$

Anybody who concentrates mostly on the more statistical and scientific studies needs often, I think, to return to these first hand accounts of what it is like to be jobless. Studies of the associations between unemployment and various measures of physical and psychological health are beset by methodological problems, and those who are more interested in statistics than individuals may begin to feel that the damage done to health by unemployment has been exaggerated. It is then that you must go back to the accounts because they paint a desperate and painful picture. Most people who are jobless for any length of time hate the experience and long for a job: their lives, experiences, and relationships begin to empty and count for much less. Harrison described it well when he said: "Prolonged unemployment is for most people a profoundly corrosive experience, undermining personality and atrophying work capacities." 16 Worse still, many of the long term unemployed are ashamed, horribly ashamed (see box)..$^{1317}$

To help readers return to these first hand accounts $I$ intend to include in each of these articles some of the voices of the unemployed. In the rest of this article I want to give some

British Medical Journal, London WC1H 9JR

RICHARD SMITH, BSC, MB, assistant editor
When I first saw unemployed men at close quarters, the thing that horrified and amazed me was to find that many of them were ashamed of being unemployed. . . .At the time nobody cared to admit that unemployment was inevitable, because this meant admitting that it would probably continue. The middle classes were still talking about "lazy idle loafers on the dole," and saying that "These men could all find work if they wanted to," and naturally these opinions percolated to the working class themselves.

GEORge ORWELl, The Road to Wigan Pier

information on how much money the unemployed have, what they do, what they eat, and how they live. This sounds as if I am about to describe a race apart, and perhaps for the long term unemployed that is not inaccurate, but the unemployed are not a uniform group-and many of them will find a job within weeks or months of leaving their last one..$^{18}$

\section{Poverty and unemployment}

The long term unemployed are likely to slip into poverty. The Department of Health and Social Security's cohort study of 2300 men who became unemployed in the autumn of 1978 showed that nearly half were receiving benefits worth less than half of their former take home pay, ${ }^{20}$ and another DHSS study of those who had been unemployed for more than a year showed that $60 \%$ had an income less than half of what it was when they were in work. ${ }^{21}$

The benefits to which the unemployed are entitled include unemployment benefit and supplementary benefit. Many of the unemployed do not receive unemployment benefit either because they have not fulfilled the contribution conditions or because they have been unemployed for more than a year. Because many do not receive unemployment benefit, because it has been cut in recent years, and because the earnings related supplement has been abolished an increasing proportion of the unemployed have come to depend on supplementary benefit: $52 \%$ in $1980-1$ but $71 \%$ in $1984-$ $5 .{ }^{22}$ Unlike unemployment benefit, supplementary benefit is means tested and extra money is paid for children. Problems with supplementary benefit include some people not taking it up, difficulties for married women in claiming it, and the fact that the higher long term rate is not paid to those who have been unemployed for over a year. The unemployed are the only group not eligible for the higher rate that is paid to all other categories of claimants who have been claiming for a year or longer.

There is no official poverty line, but many researchers take supplementary benefit as providing this. The government's advisory committee on social security has said that supplementary benefit should enable recipients "to participate in the life of the community." This means that they should be well fed and well enough dressed to maintain self respect and attend job interviews 
with confidence, have a warm home, be able to give presents to children at birthdays and Christmas, and be able to afford a newspaper and a television. ${ }^{23}$

Most of the evidence suggests that supplementary benefit does not provide these essentials to many claimants. In an official survey carried out in 1974 only one in 20 of the unemployed on supplementary benefit said that they were coping well-and most of those were single men. ${ }^{24}$ Three quarters of the men with children did not have one complete change of clothing, a warm coat, and two pairs of shoes. A more recent study looked at 1800 claimants and found that one third of the children did not have a warm coat and half had only one pair of shoes. ${ }^{25}$ Among their parents $60 \%$ lacked a standard item of clothing (a warm coat or a change of shoes), and half of the couples with children ran out of money before each week was up.

Campbell has described what these statistics mean in human terms: "One man and woman in their early 20s living in Coventry with one child, mostly unemployed since leaving school, have a total income of $£ 63$ (prices are for 1982-3), including $£ 5.25$ child benefit. Weekly bills total $£ 46 \cdot 36$ (rent $£ 27 \cdot 36$, loan payment $£ 3$, sheets and blanket club £5,

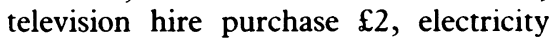
$£ 4$, gas $£ 3$, and bike payments $£ 2$ ) and their average diet is toast and porridge for breakfast, nothing at midday (the child has school dinners), sandwiches or beans on toast at tea time, cooked meals only at weekends, usually sausages or chicken and vegetables. Sometimes the woman gets vegetables from her father's garden. This is what she spent on her last three pairs of shoes: $£ 3.99$ in $1977, £ 9$ in 1980 (when she was working), and $£ 4.99$ in 1982. She has never possessed boots or winter shoes: 'I can't afford closed in shoes, so I always wear sandals and in the winter I just put on two pairs of socks.' She never buys a paper and never goes out for the evening."'

\section{Diet}

Most of the recent concern over diet in Britain has been about people eating too much, particularly too much animal fat, and, although the Black report suggested that some children were undernourished, ${ }^{26}$ there have not been many studies of the diets of the poor. An exception is a report, fam Tomorrow, from a group in Manchester who surveyed the diets of 1000 people on low incomes (about two thirds had an income less than $\$ 50$ a week) in the north of England-154 of these were unemployed. ${ }^{27}$

More than a third of the unemployed said that they or their families had had to go without a meal in the last year because they did not have enough money to buy food, and a quarter said that they did not have enough money for food all week. More than a third (39\%) said that when short of cash they cut back on food, and a fifth did not have a main meal every day because of the cost; half did not have three meals a day. The whole group were asked what they ate when shcrt of money: $38 \%$ said toast or bread, $34 \%$ eggs, $33 \%$ beans, and $32 \%$ chips. More than a third (36\%) had eaten chips in the previous 24 hours, and $56 \%$ said that they ate them several times a week or every day. In contrast, $20 \%$ said that they hardly ever or never ate fresh meat and $15 \%$ fresh or frozen fruit or vegetables.

This survey was not formally controlled, but 51 people with family income above $£ 150$ answered the survey and gave very different answers: none had gone without a meal in the last year because of lack of money, though one said that she did not have enough money for food all week; and, although six said that they cut back on food when short of money, 24 said that they cut back on holidays. The unemployed also showed more signs of hardship than the other groups with low incomes. 
Fagin and Little, in contrast, found in their study of 22 families with an unemployed man as breadwinner that alcohol consumption fell in all but one of the families - mainly because of the expense and the decrease in socialising in pubs; one man, however, began to drink heavily, which contributed to the breakup of his marriage. ${ }^{6}$ Alcohol consumption also fell sharply in a group of unemployed people after a steep increase in the price of alcohol in the 1981 budget in Britain. ${ }^{32}$ The British Regional Heart Study has also produced data on alcohol consumption among the unemployed compared with the employed, and after standardisation for age, social class, and town of residence the numbers of heavy drinkers among the employed and unemployed were not significantly different. $^{34}$

These variable findings result partly from the weakness of many of the studies (most were not designed specifically to look at unemployment and alcohol consumption), partly, Crawford et al suggest, from the different ways of measuring alcohol consumption, and partly perhaps because while most of the unemployed drink less because of shortage of money, others somehow find the money to drink much more. ${ }^{28}$ Several studies have found this polarisation in drinking habits. ${ }^{36} 37$

Crawford et al recently looked at the drinking habits of 87 unemployed men among a population of 1503 economically active men and concluded that unemployment affects drinking styles rather than quantities consumed. The unemployed consumed the same as the employed in the week of the survey but drank faster, were more likely to have had a heavy drinking day and a binge, and suffered more consequences from their drinking. ${ }^{28}$

Data on smoking and unemployed are less confusing-they all point to the unemployed smoking more than the employed. The General Household Survey 1982 showed that $55 \%$ of the un-

"My wife has known nothing but debt and poverty ever since we've been married. I know I ought to feel glad, being able to spend so much time with my kids while they're young. But what can I give them? I just feel empty. I'm ashamed I can't provide them with everything they need. What kind of a father is that? We have no life together, even though we're never apart. I've even stopped looking for work. Some days, I feel like topping myself, I'm not kidding. If there's no hope for me, what chance will they have? Life won't be worth living.

A young man in October 1983 quoted in Unemployment by JEREMY SEABROOK.

et al of almost a thousand Lothian teenagers. ${ }^{35}$ They were studied first at school when 15 and 16 and then followed up: alcohol and cigarette consumption were not significantly different four years later between the employed and the unemployed, but illicit drug use was significantly more common among the unemployed. Unemployed men seeking work had on average taken 1.4 illicit drugs compared with 0.5 among those in full time employment; among those unemployed and not seeking work the figure was $2 \cdot 8$, hinting at an underclass. Similar differences were seen in women. Looking back at when these unemployed youngsters were at school, Plant et al found no evidence that they were more "drug orientated" than those who entered full time employment. The melancholy reason for the unemployed youngsters not smoking or drinking more than the employed but taking more illicit drugs may be that it was cheaper to get "out of your head" on heroin or some other illicit drug.

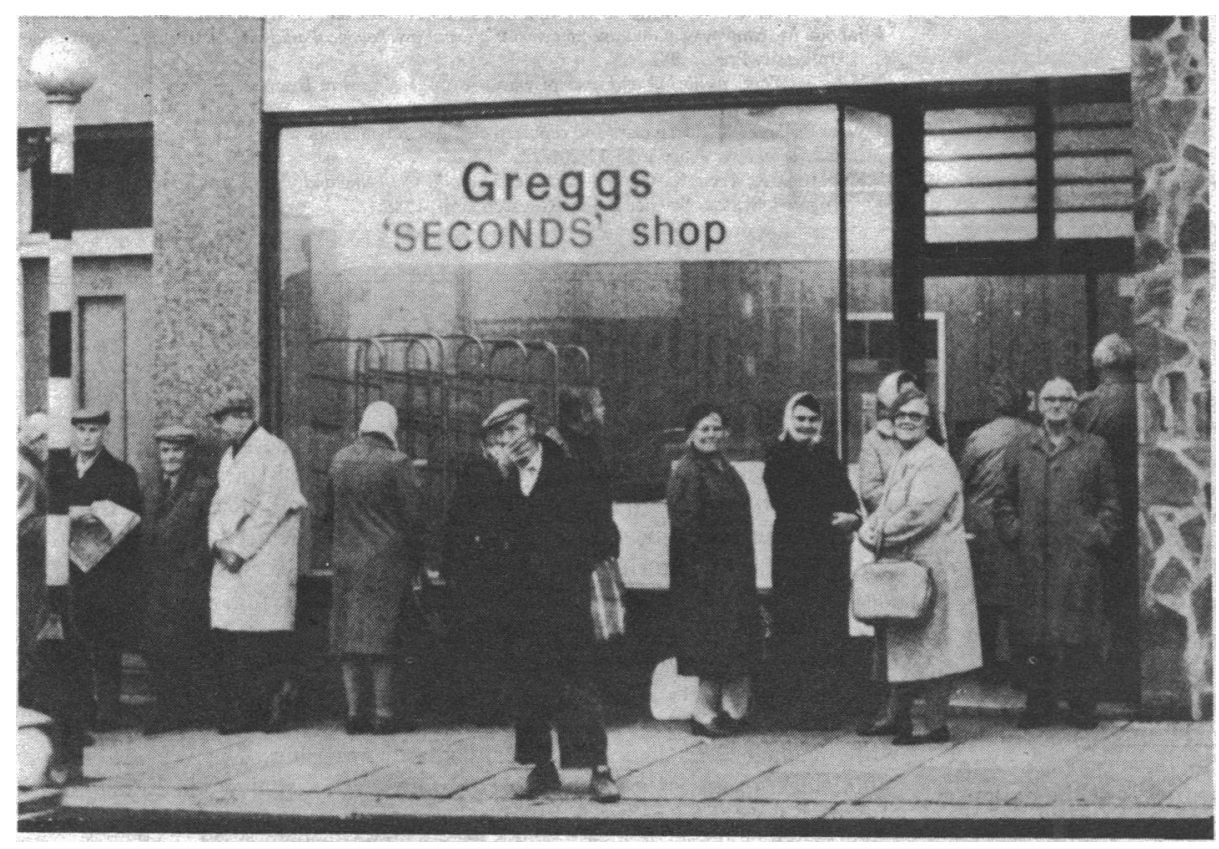

FIG 2-People queuing for stale bread in Newcastle, winter 1983. (Photograph by Jimmy Barnes.)

employed aged 16-59 were smokers compared with $38 \%$ of those employed full time: the difference was considerable for both men $(58 \% v 38 \%)$ and women $(49 \% v 37 \%))^{30}$ Fagin and Little reported an increase in cigarette consumption among both the unemployed breadwinners and their wives, ${ }^{6}$ and Cook et al found from the British Regional Heart Study more smokers among the unemployed than among the employed even after standardisation for age, social class, and town of residence. ${ }^{34}$

Illicit drug use and unemployment are both hot political issues in Britain, and many people imagine that the two are related-but few studies have investigated the relation. One that has is that of Plant and were surprised to find that the proportion of unstructured to structured time during unemployment increased on average 20 -fold.

Miles found different results when he compared more than 300 unemployed with more than 100 employed men in the Brighton area ${ }^{39}$ The unemployed did not spend much more time asleep and spent only about one more hour a day in "passive leisure," which includes watching the television and listening to the radio. But they did spend three hours more a day in domestic work, including housework, shopping, and repairs, and about another hour each in "outdoor leisure," which was mostly walking, "mooching," and lying on the beach, and "away from home leisure," 
which was mostly visiting friends and going to pubs and clubs.

Warr and Payne looked at changes in behaviour after job loss in 203 middle class and 196 working class men and found significant increases in social contact and book reading. ${ }^{40}$ There were also significant increases in domestic work and pastimes, other pastimes, and recreations, but a significant decrease in "entertainment through money."

A study from Belfast that Miles quotes suggested various strategies that unemployed men adopt for filling their time: some do passively watch the television; some throw themselves into sport or religious or civic activities; some spend much time socialising; and others devote themselves to their families. ${ }^{41}$ Despite this, most men in Miles's study said that they felt bored and restricted in what they could do-mostly because of money.

\section{Conclusion}

The unemployed are not a homogeneous group, but the longer people are unemployed the more likely they and their families are to lapse into poverty. Unemployment can also, often through a fall in income, lead to restrictions in their diet and changes in alcohol and cigarette consumption. Some important evidence suggests that the young unemployed may be more likely than their employed friends to take illicit drugs. Finally, time may hang heavily on the unemployed, and, although some seem to manage to use their time positively, many find their lives being frittered away.

All of these changes in the way people live may have effects on health, and the next six articles will examine in detail the evidence on what harm unemployment may have.

\section{References}

1 Orwell G. The road to Wigan pier. London: Victor Gollancz, 1937.

2 Campbell B. Wigan Pier revisited. London: Virago, 1984.

3 Seabrook J. Unemployment. London: Quartet, 1982.

4 Jahoda M, Lazarsfeld PF, Zeisl H. Marienthal: the sociography of an unemployed communiny.

London: Tavistock Publications, 1972. (German edition 1933.)
5 Eisenberg P, Lazarsfeld PF. The psychological effects of unemployment. Psycho Bull 1938;35: 358-90.

6 Fagin L, Little M. The forsaken families. Harmondsworth: Penguin, 1984.

Marsden D, Duff E. Workless: some unemployed men and their families. Harmondsworth: Penguin, 1975.

8 Goodman M. Unemployment in my practice: Liverpool. Br Med J 1981;282:2020-1.

9 Mackay J. Unemployment in my practice: Govan, Glasgow. Br Med f 1981;282:2104-5.

10 Husain MH. Unemployment in my practice: Rotherham. Br Med f 1981;283:26-7.

11 Tain CP. Un

11 Tanner CP. Unemployment in my practice: South Shields. Br Med $\mathcal{f} 1981 ; 283: 20$

12 Smerdon G. Unemployment in my practice: Liskeard. Br Med J 1981;283:416.

13 Higgs R. Unemployment in my practice: Walworth, London. BrMed J 1981;283:532.

14 Wilson J. Unemployment in my practice: Whitehead, Carrickfergus. Br Med F 1981;283:770.

15 Jacob A. Unemployment in my practice: Dundee. BrMed f 1981;283:1844-5.

6 Harrison R. The demoralising experience of prolonged unemployment. Employment Gazette 1976;April:330-49.

17 Greenwood W. Love on the dole. London: Jonathan Cape, 1933.

18 Hawkins K. Unemployment. Harmondsworth: Penguin, 1984.

19 Sinfield A. What unemployment means. Oxford: Martin Robertson, 1981.

20 Moylan S, Millar J, Davies R. For richer, for poorer? DHSS cohort study of unemployed men. London: HMSO, 1984

21 White M. Long term unemployment and labour markets. London: Policy Studies Institute, 1983.

22 Roll J. Better benefits for babies-financial support for pregnancy and unemployment. In: Durward L, ed. Borm unequal: perspectives on pregnancy and childrearing in unemployed families. London: Maternity Alliance, 1985.

23 Supplementary Benefit Commission. Annual report 1978. London: HMSO, 1979.

24 Clark M. The unemployed on supplementary benefit. Joumal of Social Policy 1978;7:385-410.

24 Clark M. The unemployed on supplementary benefit. Joumal of Social Policy 1978;7:385-410

25 Berthoud R. The reform on supplementary benefit. London: Policy Studies Institute, 1984.

26 Townsend P, Davidson N. Inequalities in health. Harmondsworth: Penguin, 1982. (Black report). Lang T, Andrews $\mathrm{H}$, Bedale $\mathrm{C}, \mathrm{H}$
Manchester Polytechnic, 1984.

28 Crawford A, Plant MA, Kreitman N, Latcham RW. Unemployment and drinking behaviour: some data from a general population survey of alcohol use. Br $\mathcal{Y}$ Addict 1985 (in press).

29 Wilson P. Drinking in England and Wales. London: HMSO, 1980.

30 Office of Population Censuses and Surveys. General Household Survey 1982. London: HMSO 1984.

31 Cobb S, Kasl SV. Termination: the consequences of job loss. Washington DC: National Institute for Occupational Safety and Health, 1977.

32 Kendell RE, Roumanie $M$ de, Ritson EB. Influence of an increase in excise duty on alcohol consumption and its adverse effects. Br Med f 1983;287:809-11.

33 Plant MA. Drinking careers: occupations, drinking habits, and drinking problems. London: Tavistock, 1979.

34 Cook DG, Cummins RO, Bartley MJ, Shaper AG. Health of unemployed middle aged men in Great Britain. Lancet 1982;i:1290-4.

35 Plant MA, Peck DF, Samuel E. Alcohol, drugs, and school leavers. London: Tavistock (in press).

36 Regional Working Party on Problem Drinking. Drinking problems in North East England. Newcastle upon Tyne: North East Council on Alcoholism, 1983.

37 Yates F, Hebblethwaite Thorley A. Drinking in two North East towns: a survey of the natural setting for prevention. Newcastle upon Tyne: Centre for Alcohol and Drug Studies, 1984.

38 Jahoda M. Employment and unemployment: a social psychological analysis. Cambridge: Cambridge University Press, 1982.

39 Miles I. Work, wellbeing and unemployment: a study of men in Brighton. Sussex: Science Policy Research Unit, 1983.

40 Warr P, Payne R. Social class and reported changes in behaviour after job loss. Joumal of Applied and Social Psychology 1983;13:206-22.

11 Kilpatrick R, Trew K. Quoted in: Miles I. Work. wellbeing and unemployment: a study of men in Brighton. Sussex: Science Policy Research Unit, 1983.

\section{CLINICAL CURIOS}

\section{Amputation of the cervix, an unusual self mutilation}

A 21 year old, unmarried, nulliparous woman was admitted to the maternity department of our hospital in Kibuye, Southern Burundi, with abnormal vaginal bleeding. She had noticed a swelling in her vulva for about a week and as this_-in her own words_- "annoyed her" she had cut it off with a knife. She brought the specimen with her wrapped up in banana leaves. It appeared to be the distal $1 \mathrm{~cm}$ of the cervix. She was otherwise in good health and not mentally disturbed.

The vagina was examined under general anaesthesia. The cervix had been cut off neatly, and the stump was bleeding heavily. The internal genitalia were otherwise normal. Haemostasis was achieved. The raw cervical stump was covered with epithelial flaps using Sturmdorff sutures, and the patient made an uneventful recovery.

Prolapse of the uterus in young women has resulted from severe straining at stool necessitated by rectal stricture due to lymphogranuloma inguinale. In our case, however, the patient denied any chronic constipation, and no evidence of rectal stricture was found.-CHRISTINA DE WIND, Hollum, Netherlands.

1 Lawson JB, Stewart DB. Obstetrics and gynaecology in the tropics and developing countries. London: Edward Arnold, 1967.

\section{Personal experience with brucellosis}

I describe here a personal experience of contracting brucellosis by inhalation. I spent a short holiday during the Eid celebration with my brother at Port Sudan. On returning to Khartoum, I found the airline booking was busy as usual during that time of the year. Luckily (or unluckily), however, I came across a cattle cargo aeroplane on its way to Khartoum. It had an

unscheduled landing for fueling. I explained my situation to the captainmy holidays were over and the university term had begun-and he kindly agreed to take me to Khartoum. After boarding I discovered that the environment was unbearable. The smell of animal ordure was so strong that our eyes started to lacrimate and noses run. It was a terrible experience. We had to inhale that nasty smell for the whole hour of flying. When we landed and smelled the fresh air it was like coming to a new world. It was a horrible time, but the prize was in reaching my destination in one hour instead of two days by train or bus.

I thought the ordeal was over, but a week later I developed a high fever with headache, back ache, arthralgia, and sweating. Despite a negative $\widetilde{N}$ blood test for malaria I took chloroquine, as is usual when living in an endemic area. The fever and general ill health continued, however, after finishing the course. I started to develop small, tender swollen lymph glands in the neck, axillae, and grains: symptoms of lymphadenopathy. The experience of that flight came to my mind, and I thought about brucellosis. It $\omega$ is well documented in published reports that brucellosis could be contracted by inhalation. As the blood culture could not feasibly be performed I did an agglutination test, which yielded results of $1 / 80$ for both Brucella abortus and $B$ melitensis. After consulting my colleagues I decided to take tetracycline capsules $500 \mathrm{mg}$ six hourly, and on the third day the fever started to drop and the tender lymph gland and arthralgia eased down. I repeated the agglutination test a week later and found the results to be $1 / 160$ for $B$ melitensis.

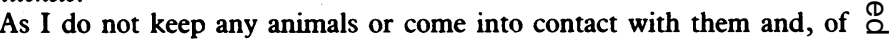
course, I do not drink any fresh milk or eat raw meat I think the only way I could have got brucellosis was by inhalation during that terrible flight. I conclude, therefore, that brucellosis is a real hazard for the staff working in cattle and sheep cargo aeroplanes as well as unfortunate casual passengers like me.-G M MALIK, lecturer in medicine, Wad Medani, Sudan.

\section{ग}

